\title{
PROGRAM KEMITRAAN MASYARAKAT USAHA KERIPIK PISANG DI DESA WAOWANGI KECAMATAN SAMPOLAWA
}

\author{
Ernawati Malik ${ }^{1}$, LM Hasrul Adan ${ }^{2}$, Muhammad Rais $^{3}$, Rudi Abdullah ${ }^{4}$, Asrianti Dja'wa ${ }^{5}$, \\ Ani $^{6}$, Siti Haryati Dastri ${ }^{7}$, Aswiani ${ }^{8}$, Sukma Rahmawati', \\ Wiyanti $^{10}$, Noval ${ }^{11}$, Fiki Andriani ${ }^{12}$, Muhammad Taufik ${ }^{13}$, Nuriasi ${ }^{14}$ \\ ${ }^{1,2,3)}$ Dosen Program Studi Akuntansi, Fakultas Ekonomi, Universitas Muhammadiyah Buton, \\ Kota Baubau, Sulawesi Tenggara. \\ 4) Dosen Program Studi Manajemen, Fakultas Ekonomi, Universitas Muhammadiyah Buton, \\ Kota Baubau, Sulawesi Tenggara \\ ${ }^{5)}$ Dosen Jurusan Ekonomi Pembangunan, Fakultas Ekonomi dan Bisnis, Universitas Halu Oleo, \\ Kota Kendari. \\ 6,7,8,9,10,11,12,13,14) Mahasiswa Program Studi Manajemen, Fakultas Ekonomi, Universitas Muhammadiyah \\ Buton, Kota Baubau Sulawesi Tenggara \\ email: rudiazra9140@gmail.com
}

\begin{abstract}
Abstrak
Kripik pisang biasanya masih diproduksi oleh industri rumahan dengan skala usaha yang relatif masih kecil. Industri rumahan sangat populer dalam masyarakat hal ini disebabkan oleh sedikitnya aplikasi IPTEK dalam proses pengolahan serta masih minimnya metode pemasaran. Bersumber pada latar balakang diatas maka kami melakukan aktivitas Pengabdian Kepada Masyarakat (PKM) dengan mitra melakukan produksi keripik pisang, yang terletak di desa Waowangi Kec. Sampolawa, Kab. Buton Selatan, Prov. Sulawesi Tenggara. Aktivitas Pengabdian yang dilakukan adalah pelatihan dan sosialisasi kepada para pengusaha pembuatan Kripik Pisang dengan bahan utamanya pisang Kapuk, pemberian dorongan perlengkapan serta bahan membuat tingkatkan penciptaan, sosialisasi kemampuan terhadap Sumber Daya Manusia dalam berwirausaha, strategi pemasaran usaha serta kerja sama, mendampingi dalam mendesain kemasan, membantu mengurus sertifikat izin edar serta sertifikat halal, kenaikan pemasukan mitra meningkat menjadi dua kali lipat dari tadinya. Aktivitasnya bisa dijelaskan kalau pemasalahan yang dialami oleh pengusaha saat dulu dan sekarang bisa dilihat sesudah mengadakan kegiatan pengabdian kepada masyarakat atau dunia usaha khususnya pengusaha kripik Pisang.
\end{abstract}

\section{Kata Kunci: Keripik Pisang, Wirausaha}

\begin{abstract}
Banana chips are usually still being created by home industries on a small scale.The home industry is popular in enhancing creation because of the minimal application of science and technology in the processing process and the lack of marketing methods. Base on this background, we carry aot dedication activities for the Pengabdian Kepada Masyarakat (PKM) with dedicated banana chips producers. Which is located in the Desa Wawoangi Kecamatan Sampolawa Kota Baubau Propinsi Sulawesi Tenggara. Dedicated activities carried out are training in making banana chips, providing encouragement for equioment and materials to increase creation, training in entrepreneurial human resource management, technical tutorials on marketing strategies and cooperation, assistance in making packaging label designs, Assisting PIRT permits and halal certificates, increasing income. Partners so 2 times more then before. Fron this activity, it can be concluded that the problems experienced by partners before the dedication activities can be resolved after exploring community service activities.
\end{abstract}

Keywords: Banana Chips, Entrepreneur 


\section{PENDAHULUAN}

Buah yang paling banyak mengandung vitamin dan memiliki khasiat adalah Buah Pisang. Didalam buah pisang terdapat gizi yang sangat baik, dimana menjadi sumber kekuatan atau tenaga bagi kita yang mengkonsumsinya dibandingkan berbagai jenis buah yang lainnya. Pisang menciptakan tenaga 136 kalori per 100 gram. Mineral banyak tekandung dalam buah pisang, kalium, magnesium, besi, fosfor, serta kalsium, memiliki vit B serta C, pro vit A (betakaroten). "Buah pisang bisa di mengkonsumsi dalam wujud fresh maupun diolah jadi wujud santapan lain semacam pisang rebus, pisang goreng, kolak pisang, keripik pisang, serta aneka wujud olahan santapan yang lain ( Suyanti serta Supriyadi, 1998)". Bahan makanan dari pisang dimana disebut juga kripik pisang merupakan olahan makanan yang digemari oleh masyarakat. Pisang yang sangat sesuai buat di buat keripik merupakan pisang batu ataupun pisang kepok. Tipe pisang ini mempunyai wujud yang bundar besar, daging buahnya padat, serta renyah sehabis di goreng.

\section{METODE}

Sesi persiapan yang dibutuhkan adalah mengumpulkan semua data yang memiliki kaitan terhadap aktivitas kegiatan dalam mempersiapkan semua kegiatan yang dibutuhkan dalam menyelesaikan aktivitas. Bagian ini terdiri atas :

1. Melakukan pelatihan tentang cara membuat pisang kripik dengan melakukan koordinasi secara terus menerus dengan mitra usaha.

2. Penentuan pembagian beban kerja harus di diskusikan oleh anggota regu sehingga anggota regu memiliki pekerjaan yang sama.

3. Pelatihan yang dilakukan harus mempersiapkan semua bahan utama dan perlengkapanya

4. Melakukan koordinasi dengan berbagai pihak terkait yang berhubungan langsung dengan kegiatan ini.

\section{HASIL DAN PEMBAHASAN}

Menjajaki aktivitas Sosialisasi dalam membuat keripik pisang memiliki antioksidan. Memperoleh cara mengenai metode menentukan bahan dasar keripik dari pisang yang bermutu, proses pembuatan keripik dari pisang memakai kunyit yang menjadi sumber antioksidan sekalian selaku perona natural serta memperoleh dorongan perlengkapan serta bahan yang dibutuhkan buat tingkatkan penciptaan keripik pisang. Menjajaki tutorial teknis strategi marketing serta kerjasama. Ulasan mengenai hasil pekerjaan ini, bisa menyusun strategi marketing serta sanggup menjalakan usaha bersama antara minimarket sebagai tempat menitip atau menjual makanan olahan yang terbuat dari pisang. 


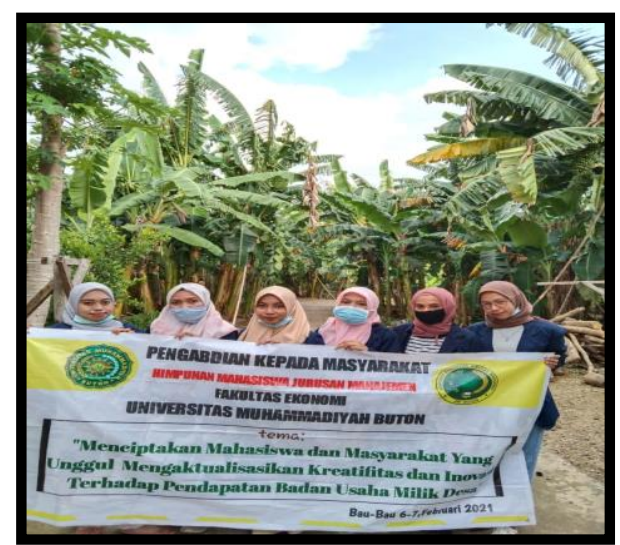

Gambar 1

Lokasi Kebun Pisang Kapuk

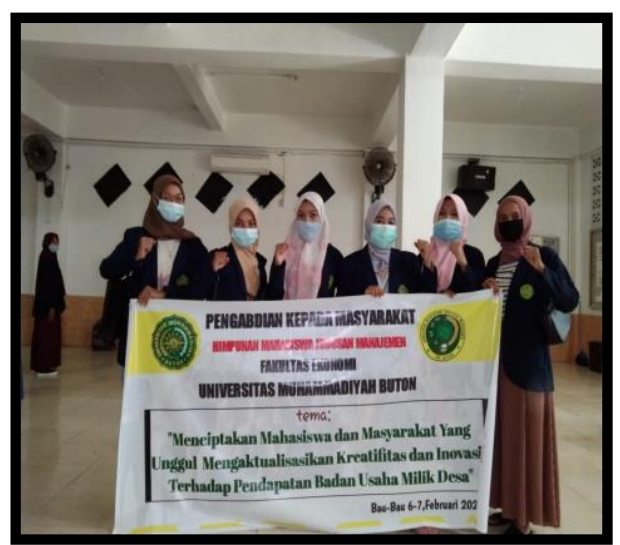

Gambar 2

Lokasi Pemasaran Kripik Pisang

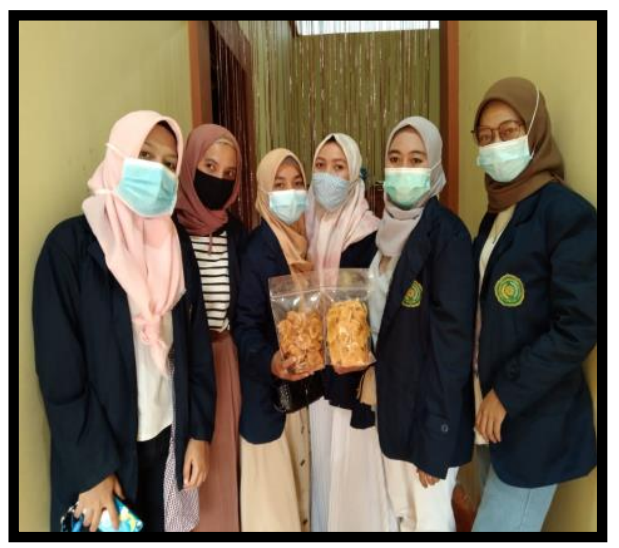

Gambar 3

Rumah produksi Kripik Pisang

\section{SIMPULAN}

Dari aktivitas Kegiatan Pengabdian Kepada Masyarakat yang telah dilaksanakan bisa disimpulkan, kalau selesai melakukan kerjasama Pengabdian kepada Masyarakat maka selanjutnya melihat keahlian pengusaha dalam hal membuat keripik dari pisang bertambah, kenaikan skala penciptaan, bahan keripik dari pisang mempunyai izin P- IRT serta memiliki sertifikat halal, kenaikan pemasukan mitra jadi 2 kali lipat dari tadinya. Kasus yang di hadapi oleh mitra saat sebelum aktivitas dedikasi bisa di selesaikan sehabis menjajaki aktivitas dedikasi PKM ini.

\section{SARAN}

Saran- saran buat buat riset lebih lanjut buat menutup kekurangan riset. Tidak muat saransaran diluar buat riset lanjut

\section{TERIMA KASIH}

Tim Pengabdian Kepada Masyarakat mengucapkan terima kasih kepada Universitas Muhammadiyah Buton yang memberikan dukungan dana dan Kepala Desa Wawoangi yang menyediakan fasilitas dan data yang kami butuhkan.

\section{DAFTAR PUSTAKA}

Abdullah, Rudi, and Asrianti Dja'wa. "Pelatihan Pengelolaan Keuangan Badan Keswadayaan Masyarakat (Bkm) Di Kelurahan Lipu Kota Baubau Sulawesi Tenggara." Prosiding Konferensi Nasional Pengabdian Kepada Masyarakat dan Corporate Social Responsibility (PKM-CSR) 2 (2019): 1494-1508. 
Abdullah, Rudi. "Pelatihan Pengelolaan Keuangan Kelompok Masyarakat (POKMAS) di Kelurahan Lipu Kota Baubau Sulawesi Tenggara." Proceeding of The URECOL (2020): 31-39.

Pratiwi, E. T., Abdullah, R., \& Abdullah, L. O. D. (2018). Training of Financial Management on Society Self-Helping Agency at Kelurahan Palabusa, Baubau City, Southeast of Sulawesi. Seminar Nasional dan The 5th Call For Syariah Paper (SANCALL) 2018.

Januari Suyanti, dan Supriyadi, A., 2008. Pisang, Budi Energi, Pengolahan, dan Prospek Pasar. Jakarta: PenebarSwadaya. 